\title{
Governmental-Funded Religious Associations and Non- Discrimination Rules: On Immunity and Public Funding
}

\author{
Nahshon Perez
}

\section{Introduction}

Many religious associations exhibit internal norms that differ from liberal norms and rules. Such norms often directly contradict the non-discrimination norms and rules that are part and parcel of the liberal democracies in which these associations operate. Religious associations often are considered, in both legal and scholarly writings, exempt from at least some of these norms and rules. This tension between broad societal non-discrimination ${ }^{1}$ rules and the norms of specific religious associations has won the attention of scholars and courts. ${ }^{2}$ In many such

\begin{abstract}
This article has greatly benefitted from suggestions and comments from the following scholars: Micah Schwartzman, Sune Lægaard, Simon Thompson, Suzanne L Stone, Yair Lorberbaum, and Berachyahu Lifshitz. It was presented at the "Secularism, Separation, (Non-) Establishment: The Liberal State vs. Religion?" workshop (June 2019) at the University of Konstanz (kindly arranged by Aurélia Bardon), and at the Humanities, Judaism and Jurisprudence Research Group at the Van-Leer Jerusalem Institute (May 2019), and the feedback received is gratefully noted. Funding for this research was received from the Israel Science Foundation grant number 688/18.

Nahshon Perez, Senior Lecturer, Department of Political Studies, Bar-Ilan University. nahshonp@gmail.com
\end{abstract}

1. Discrimination will be understood here as "acts, practices, or policies that impose a relative disadvantage on persons based on their membership in a salient social group": Andrew Altman, "Discrimination" in Edward N Zalta, ed, The Stanford Encyclopedia of Philosophy (Winter 2016 ed), online: https://plato.stanford.edu/cgi-bin/encyclopedia/archinfo.cgi? entry=discrimination \&archive $=$ win 2016 .

2. See, e.g., Stuart White, "Toleration of religious discrimination in employment" in Catriona McKinnon \& Dario Castiglione, eds, The Culture of Toleration in Diverse Societies (Manchester University Press, 2003) 179; Seana Valentine Shiffrin, "What is Really Wrong with Compelled Association?" (2004-2005) 99:2 Nw UL Rev 839; Andrew Koppelman, "Signs of the Times: Dale v. Boy Scouts of America and the Changing Meaning of Nondiscrimination" (20012002) 23 Cardozo L Rev 1819; Andrew Shorten, "Accommodating religious institutions: Freedom versus domination?" (2017) 17:2 Ethnicities 242 [Shorten 2017]; Andrew Shorten, "May Churches Discriminate?" (2019) 36:5 J Applied Philosophy 709; Ruth HalperinKaddari, "Women, Religion and Multiculturalism in Israel" (2000) 5:2 UCLA J Int'l L \& Foreign Aff 339; Aviad Rubin, "The status of religion in emergent political regimes: lessons from Turkey and Israel" (2013) 19:3 Nations and Nationalism 493; Paul Billingham, "How Should Claims for Religious Exemptions be Weighed?" (2016) 6:1 Oxford J Law and Religion 1; Nahshon Perez \& Elisheva Rosman-Stollman, "Balaniyot, Baths and Beyond: Israel's State-Run Ritual Baths and the Rights of Women" (2019) 7:2 JL Religion \& State 184. In the US context, see Hosanna-Tabor Evangelical Lutheran Church and School $v$ Equal Employment Opportunity Commission (2012), 565 US 171 [Hosanna-Tabor]. In this case, the Supreme Court of the United States held that federal discrimination laws do not apply to religious organizations' selection of religious ministers. This is an often-cited case demonstrating religious associations' immunity from non-discrimination rules (in this case, a disability act). 
debates, the background assumption is that these religious groups are voluntary associations functioning within a model of separation between religion and state; that is, such associations operate through the free choices of their members and individuals are as free to leave the associations as they were to form them. ${ }^{3}$ While theorizing about non-discrimination rules and whether they apply to religious associations that are funded via the contributions of their members is of obvious importance, this article examines a distinct problem: that of discrimination within religious associations that are directly supported by democratic governments. Recent research on religion-state relations ${ }^{4}$ has pointed out that, in many democratic countries, religious associations are funded by the government to a considerable extent. The tension between non-discrimination norms and the presumed rights of the state-funded religious associations to be exempted from such rules, however, is neglected in the literature. Perhaps this is because the most prominent legal cases of this kind were tried at the European Court of Human Rights ${ }^{5}$ and the U.K. Supreme Court, ${ }^{6}$ rather than the more conspicuous U.S. Supreme Court. This article asks the following question: in what way, if at all, does receiving governmental funding change the presumed right of religious associations to be exempted from non-discrimination rules? The 'immunity thesis'- the idea that religious associations enjoy the right to be exempted from non-discrimination rules-is not challenged here: this article argues that if there is such a right to

3. This can be seen most clearly in the lack of a dedicated discussion of the possibility that such associations are supported by the government. See, e.g., Lawrence Sager, "Why Churches (and, Possibly the Tarpon Bay Women's Blue Water Fishing Club) Can Discriminate" in Micah Schwartzman et al, eds, The Rise of Corporate Religious Liberty (Oxford University Press, 2016) 77; Bruce N Bagni, "Discrimination in the Name of the Lord: A Critical Evaluation of Discrimination by Religious Organizations" (1979) 79:8 Colum L Rev 1514; Shiffrin, supra note 2; John Corvino et al, Debating Religious Liberty and Discrimination (Oxford University Press, 2017).

4. See, e.g., Jonathan Fox, Political Secularism, Religion, and the State: A Time Series Analysis of Worldwide Data (Cambridge University Press, 2015); Nahshon Perez \& Jonathan Fox, "Normative theorizing and political data: toward a data-sensitive understanding of the separation between religion and state in political theory" (2018) Critical Review of Int'l Social and Political Philosophy 1.

5. See, e.g., Martinez v Spain, 2014 ECHR 170 (application no 56030/07) [Martinez]. This case involved the discontinued employment of a Catholic teacher. While employed by the state (Spain) in a public school, his position required the approval of the Catholic Church. Approval was withheld-even though his teaching evaluations were impeccable-after it became known that, while officially a priest, he was married with children. In a 9-8 ruling (rich with references to canon law), the ECHR held in favour of the Catholic Church. Notably, the Court held, at para 131, that the defense accorded to the religious association's autonomy is limited to cases where the ability of the association to exercise its religious autonomy is threatened, the risk is probable and substantial, and the means chosen do not go beyond what is necessary to serve the goal of protecting said autonomy. This case will be used as an example for the deliberations to follow.

6. See, e.g., $R(E) v$ Governing Body of JFS [2009] UKSC 15 [JFS]. In this case, the Jewish Free School in London (a governmental funded faith school) was compelled to change its admission policies which previously included an examination of the matriline of admitted students. The UKSC held that this criterion violates non-discrimination rules in the UK Race Relations Act of 1976. The decision is rich with references to Jewish law. This case will also be used as an example for the deliberations to follow. On this case, see Haim Shapira, "Equality in Religious Schools: the JFS Case Reconsidered" in Leora Batnitzky \& Hanoch Dagan, eds, Institutionalizing Rights and Religion (Cambridge University Press, 2017) 164. 
immunity, receiving governmental funding does not necessarily eliminate it. Much depends on how each case maintains the balance between the autonomy of religious associations $\mathrm{s}^{7}$ and the protection of individual citizens from discrimination that impacts important civil interests such as access to jobs or high-quality education. Of the suggested variables identified to test this balance, three are internal to the associations' structure: the centrality of the potentially illiberal norm to the funded religious association; the kind of violation of non-discrimination rules (either internal or external discrimination, see below); and the willingness of the religious association to internalize the cost of the discrimination. Two additional variables that can be used to test the balance of competing social values are external to the association and depend on the political-legal environment in which the association functions: the quantity of funding that the government makes available to the association, and the process by which potentially competing religious associations can become eligible for recognized and funded status. A multivariable 'test' is required in order to determine whether and how governmental funded religious associations can still claim immunity when practicing discriminatory norms.

This article will be structured in the following way: Section A examines the rationale and structure of the noted immunity provided (at least prima facie) to religious associations. It is divided into three subsections: A.1. discusses freedom of association, A.2. explores freedom of the church, and A.3. distinguishes between external and internal discrimination conducted by religious associations. Section B presents data that succinctly establishes the prevalence of public funding of religious associations in democratic countries, and hence outlines the magnitude of the phenomena discussed in the current article. It then explains three reasons that receiving such public funding would particularly affect the immunity of religious associations: considerations of equality, justifiability, and the difficulties expected from the entanglement of religion and state that would arise when governments fund religious associations. Section $\mathrm{C}$ presents a multivariable test for evaluating the legitimacy and extent of 'immunity' in cases where governmental-funded religious associations practice discriminatory norms and demonstrates the utility of this multivariable test via an analysis of the ECHR Martinez case (supra note 5).

\section{A. The Immunity Thesis: An Introduction}

The immunity thesis can be defined as follows: religious associations should have the right to be exempted from non-discrimination norms and rules. ${ }^{8}$ The goal of

7. As defined by Laycock: "A church autonomy claim is a claim to autonomous management of a religious organization's internal affairs": Douglas Laycock, "Church Autonomy Revisited" (2009) 7 Geo JL \& Pub Pol'y 253 at 254. See Shorten 2017, supra note 2 for a critical analysis of this notion.

8. A clear example (with regard to funded faith schools in the UK) can be found in schedule 11, part 2 of the UK Equality Act 2010, available at: https://www.legislation.gov.uk/ukpga/2010/ 15/schedule/11. Section 2.3 of the UK department of education document regarding the 2010 equality act advises: "Schools with a religious character (commonly known as faith schools) 
this section is to succinctly present the rationale grounding this thesis and to distinguish two kinds of discrimination that this immunity might defend. While there are different ways to justify the immunity thesis, arguably the two most prominent reasons are freedom of association and the historical idea of freedom of the church. I examine each justification, and then turn to the distinction between internal and external discrimination. As a preliminary note: the goal of this article is to examine how receiving public funding impacts the immunity thesis, not to argue that the immunity thesis is justified. This article accepts that the immunity thesis plays an important role in contemporary political and legal discourse, and aims to address a lacuna in scholarly literature regarding how immunity fares vis-a-vis public funding.

\section{A.1. The immunity thesis and freedom of association}

As scholars and international treaties have articulated, the ability of individuals to maintain religious beliefs - often grounded in notions of freedom of conscience (forum internum) — is an important public interest and a recognized right. ${ }^{9}$ This right to have, change, or reject such religious beliefs is accompanied by legal protection for conduct and behaviours that demonstrate such beliefs (forum externum). While the protected range of such conduct is not limitless, several actions - the ability to pray, attend religious places of worship, attend religious ceremonies, and other similar practices-are established in legal documents and in scholarly writings. ${ }^{10}$ These protected religious beliefs and conducts are often group activities that require a community of persons sharing the same beliefs and conduct. In fact, across religions, multiple participants are often necessary for the

\footnotetext{
have certain exceptions to the religion or belief provisions which allow them to discriminate because of religion or belief in relation to admissions and in access to any benefit, facility or service" (document on file with the author). In Martinez, supra note 5 at para 154, the ECHR stated: "the applicant complained that the decision not to renew his contract had unjustifiably given precedence to the Church's rights to religious autonomy and to freedom of association over his right to respect for his private life. In his view, a new "right to dismiss", of a discriminatory nature, had thus been created in favour of religious entities." As the applicant's teaching skills and evaluations were excellent, his private life alone (i.e. that he was married with children and supported the legitimacy of optional celibacy for priests) contributed to his dismissal. These are variables that would be considered discriminatory in non-religious labour contexts (which would focus solely on the quality of the applicant's teaching, see para 20 of Martinez). In the US context, Hosanna-Tabor, supra note 2 , is the leading case demonstrating this category (via the phrase 'ministerial' exception).

9. See Heiner Bielefeldt et al, Freedom of Religion or Belief: An International Law Commentary (Oxford University Press, 2016) at 55-91; Ronald Dworkin, Religion without God (Harvard University Press, 2013) at 10-21.

10. See, e.g., Bielefeldt, supra note 9 at 92-190; Michael W McConnell, "Why is Religious Liberty the First Freedom?” (1999) 21 Cardozo L Rev 1243; Vincent Phillip Muñoz, "Two Concepts of Religious Liberty: The Natural Rights and Moral Autonomy Approaches to the Free Exercise of Religion” (2016) 110:2 American Political Science Rev 369.
} 
fulfillment of one person's religious duties. Thus, there is a close affinity between individual religious liberties and the freedom of association. ${ }^{11}$

Furthermore, in many religions, houses of prayer also function as community centers. Prayer houses often facilitate activities such as learning, arranging collective giving to charity, solving community problems and creating community cohesiveness in general. It is worth questioning whether this more social conceptualization of religious liberty (as connected to freedom of association) can be grounded in the narrow justification of freedom of conscience. While some of the religious actions of a community mandate the participation of several people, other group actions function as social rather than worship activities. For many religious groups, however, this social function and its role in fostering group cohesiveness proves just as important as more narrowly conceived religious duties. That is because these social functions create an environment in which religious identity is built in childhood and maintained throughout individuals' lives. ${ }^{12}$

This more expansive, sociological understanding of the connection between religious liberty and the freedom of association explains why many religions require the creation of spaces which are exclusively, or almost exclusively, religious. This point is important for many religious individuals who are almost always integrated into a wider, heterogenous society. These homogeneous spaces only exist in a rather narrow aspect of the believer's life- usually specific religious spaces (prayer houses, faith schools) that are required for the continued existence of the religious association.

This description explains why, if religious liberty is important, it must be accompanied by a robust freedom of association that facilitates its fulfillment in a community or association of like-minded individuals. This associational structuring of like-minded religious individuals also mandates the exclusion of individuals who do not share the relevant beliefs, even if that exclusion is in tension with broader, democratic norms of societal inclusion. For example, an association of religious individuals who all believe that members of the clergy cannot be women will have the right to discriminate against women when they select members of their clergy. Furthermore, the members of the association will have the right to exclude from their association individuals that take for granted that women can be members of the clergy (and this latter group also has the freedom to form their own association and religious creed). ${ }^{13}$ To conclude: if

11. See Kent Greenawalt, "Freedom of Association and Religious Association" in Amy Gutmann, ed, Freedom of Association (Princeton University Press, 1998) 109; Natan Lerner, "Religion and Freedom of Association" in John Witte Jr \& M Christian Green, eds, Religion and Human Rights: An Introduction (Oxford University Press, 2011) 218.

12. This is well-recognized by classic sociological research. See Emile Durkheim, The Elementary Forms of Religious Life, translated by Karen E Fields (Free Press, 1995 [1912]) at 33-39; Steven Lukes, Emile Durkheim, His Life and Work: A Historical and Critical Study (Stanford University Press, 1985) at 461.

13. This is a well-established view of freedom of association in liberal theory. See Brian Barry, Culture and Equality (Polity, 2001) at 155-62. As Barry noted at 158, this view will demand that the costs of exiting the association would be limited to those intrinsic to the associational life and have no further implications for the person exiting. The source of this view is John Locke, "A Letter Concerning Toleration" in Richard Vernon, ed, Locke on Toleration (Cambridge University Press, 2010 [1689]). 
religious liberty is important, then it demands - via freedom of association-a version of the immunity thesis.

\section{A.2. The immunity thesis and freedom of the church}

The word church historically denotes the Catholic Church, yet this term has been expanded here to include any religious association. ${ }^{14}$ The freedom of the church (libertas ecclesiae), simply put, refers to the idea that the church should have sovereignty when managing its own internal affairs. This includes issues such as religious doctrines, appointments to religious positions, determination of membership, the proper way to deal with dissenters, and the like. ${ }^{15}$ This idea that churches should enjoy institutional sovereignty in their affairs, and immunity from governmental intervention, has historical roots in the complex relations between church and state in Europe. These relationships-including the investiture contest, the Spanish inquisition, and the wars of religion following the reformation-were at times violent and conflict ridden; through these conflicts, the idea that originated with the status of the Catholic Church gradually was understood to include other Christian religious institutions. Thus the idea of the freedom of the church that has won the attention of legal scholars and historians is intertwined with the historical events of European Christendom. For us, the primary point of importance from this complicated history is that churches and other religious institutions' claim to institutional sovereignty to manage their affairs independent from state interruption and involvement, became a recognized argument in legal and political discourse. ${ }^{16}$

The reasons that are given to justify the continuing freedom of the church, however, can be confusing and need to be carefully untangled. From the perspective of the church (used here as a shorthand for any religious association), the justification for the freedom of the church is based on that institution's hold on the theological truth; therefore, allowing external governmental intervention in its affairs might compromise the church's ability to promote religious truth. ${ }^{17}$

Outside of a given theological perspective, a second more mundane rationale for the freedom of the church is the historical, or realistic reason: namely, that religious institutions are special, not in the sense that they hold the true

14. See Barry, supra note 13 at 155-62.

15. See Michael W McConnell, "The Origins and Historical Understanding of Free Exercise of Religion” (1989) 103:7 Harvard L Rev 1409; McConnell, Why is Religious Liberty the First Freedom?, supra note 10; Norman Doe, Law and Religion in Europe: A Comparative Introduction (Oxford University Press, 2011) 114-37.

16. See, e.g., Richard W Garnett, "The Freedom of the Church" (2007) 4:1 J Catholic Social Thought 59; R Southern, The Penguin History of the Church: Western Society and the Church in the Middle Ages (Penguin Books, 1990 [2016]) at 36-43, 125-31; Paul Horwitz, "Freedom of the Church without Romance" (2013) 21 J Contemp Leg Issues 59; Brian Tierney, "Religion and Rights: A Medieval Perspective" (1987) 5:1 JL \& Religion 163.

17. The classic expression of this view was pronounced by Pope Gregory VII (1015-1085) in his Dictatus papae (1075). See Rainer Forst, Toleration in Conflict (Cambridge University Press, 2013) at 60-61; Brian Tierney, The Crisis of Church and State 1050-1300 (University of Toronto Press, 1988). 
theological set of beliefs, but that they are unique and socially sensitive entities. This view grounds the freedom of the church in general prudential considerations. ${ }^{18}$ Governmental intervention in the internal affairs of the church, seen from this perspective, might lead to severe social unrest.

Claims of theological truth as justification for the freedom of the church are difficult, if not impossible, to translate into liberal discourse ${ }^{19}$ since they cannot be understood easily outside of the contours of a particular faith. However, the idea that the church should enjoy immunity from governmental intervention following prudential reasons is based on historical realism and not grounded in theological considerations; this more mundane, sociological grounding of freedom of the church can be critically used in a secularized and pluralistic environment, and thus it is the relevant grounding for the concerns of the current article. ${ }^{20}$

\section{A.3. The immunity thesis and internal and external discrimination}

The claims that religious associations make for strict autonomy should be evaluated vis-à-vis other interests, most importantly non-discrimination rules and norms. In order to properly evaluate the potential collision between these norms and religious autonomy, we need to distinguish between two kinds of discrimination enacted by religious associations: internal and external. The first, the 'internal,' denotes cases in which religious associations discriminate against their own members and/or clergy. The second, the 'external,' denotes cases in which religious associations discriminate against non-members (typically to be found at the work-environment of the religious association). While the lines between 'internal' and 'external' will blur at times, the distinction is important.

Internal discrimination can be found among many religious associations as they adopt in-egalitarian, even discriminatory, norms among members and clergy of their own associations. For example, women cannot be members of the clergy

18. See Locke, supra note 13 at 15 ; Steven D Smith, "Unprincipled Religious Freedom" (1996) 7 J Contemp Leg Issues 497; Judith N Shklar, "The Liberalism of Fear" in Nancy L Rosenblum, ed, Liberalism and the Moral Life (Harvard University Press, 1989) 21. Note that the prudential argument is a natural companion to the idea that the state is ill-equipped to deal with theological and religious issues. The 'ill-equipped' argument has roots in Locke, writing on political leaders: "Neither their right to rule nor their skill in ruling entails certain knowledge of other things, let alone of true religion. If it did, how does it come about that in matters of religion the lords of different countries differ so much from one another?" (Locke, supra note 13 at 19). Contemporary versions of this argument include Suzanne Last Stone, "Religion and state: Models of separation from within Jewish law" (2008) 6:3-4 Int'l J Constitutional Law 631; Yuval Jobani \& Nahshon Perez, Women of the Wall: Navigating Religion in Sacred Sites (Oxford University Press, 2017) 143-74.

19. See Richard C Schragger \& Micah Schwartzman, "Lost in Translation: A Dilemma for Freedom of the Church" (2013) $21 \mathrm{~J}$ Contemp Leg Issues 15.

20. The well-known worry, often raised in US legal and political circles regarding the urgent need to avoid entanglement of religion and state, stems from the same realistic, historical concern regarding the special sensitivity of churches. See Barry, supra note 13 at 19-25. The famous legal expression of this 'realistic' concern is the following line delivered by Chief Justice Burger in Lemon v Kurtzman (1971), 403 US 602 at 622: "political division along religious lines was one of the principal evils against which the First Amendment was intended to protect." 
in many religions. Similar restrictions apply to members who openly identify as homosexual, lesbian, or transgender. Such norms would be illegal in most liberal democratic labour contexts. ${ }^{21}$ However, immunity from non-discrimination rules is often claimed by, and at times granted to, religious associations. The justifications for such exceptions typically invoke the freedom of association and/or the freedom of the church described above. For reasoning that relies on the freedom of association, the justification for the immunity is, roughly, that membership in such associations is voluntary. If women, LGBT persons, or any other members of the association are unhappy with the internal inegalitarianism of the association, the immunity thesis argues, they can leave and form a new association. Furthermore, the forming of the association is necessary for the performance of the religious liberty of the members who view such internal inegalitarianism and discrimination as part and parcel of their beliefs (and such members formed the association via their own contributions). The following quote from the majority opinion in Martinez demonstrates this point: "As regards the autonomy of faith groups, the Court notes that religious communities traditionally and universally exist in the form of organised structures ... the right of believers to freedom of religion encompasses the expectation that they will be allowed to associate freely, without arbitrary State intervention. The autonomous existence of religious communities is indispensable for pluralism in a democratic society and ... has a direct interest, not only for the actual organisation of those communities but also for the effective enjoyment by all their active members of the right to freedom of religion." 22 And the court continues: "in the event of any doctrinal or organisational disagreement between a religious community and one of its members, the individual's freedom of religion is exercised by the option of freely leaving the community." 23

External discrimination can be characterized, roughly, as follows: religious associations at times wish to expand discriminatory norms that apply to clergy and members; to, mutatis mutandis, employees of the association, or (more broadly) to persons that are commercially involved with the association. Such persons might be discriminated against by the association, as a part of the association's effort to create the homogeneous space required for the association to educate its children and enable an environment that is conducive to the religious-communal way of life.

The ECHR case of Martinez again can serve as an example. The Catholic Church viewed Martinez as unfit to teach its religion, as he violated its core theological beliefs. According to the Church, allowing Martinez to keep his teaching position would have created the wrong impression for children and their parents. In an official memorandum issued by the Diocese following Martinez' dismissal

21. Note that the selection of members is to be counted as an internal discrimination, otherwise the association will be unable to be faithful to the specific religious doctrine favored by the members.

22. Martinez, supra note 5 at para 126 .

23. Ibid at para 127. 
from his position as a teacher, the Diocese observed: "The Diocese of Cartagena regrets this situation, while pointing out that the decision was taken also out of respect for the sensitivity of many parents who might be upset to learn of the situation of [the applicant], who was teaching Catholic religion and ethics in an education centre." 24

At this point, a schematic 'map' of the justifications for the immunity thesis and the categories of discrimination is required to analyze arguments for 'immunity' properly. We have in front of us two types of justifications (freedom of association and freedom of the church), and two kinds of discrimination (internal and external).

Let us start with the freedom of association grounding of the immunity claim. If freedom of association is the grounding reason for granting immunity to religious associations, internal discrimination would be permissible: otherwise the freedom of association for individuals who accept this discrimination would not be respected. However, under regular circumstances, external discrimination is not permitted by this logic as the persons discriminated against are not members of the association. ${ }^{25}$ Put in other words, the justification for immunity by freedom of association, by its own internal logic, does not extend to non-members of the association. Since non-members do not exercise the same freedom of association as the noted group — that is, they are not a part of the relevant community - the freedom of association justification for immunity does not extend to external discrimination unless a further justification for that external discrimination is demonstrated. Put differently, a given community wishing to justify external discrimination would have to demonstrate why the internal norms of the group entail, and justify, external discrimination; any such step should be viewed skeptically as it would broaden the meaning of freedom of association in such a way as to disregard important interests for non-members of the association. ${ }^{26}$

24. Ibid at para 18 . Note that the Catholic Church stripped the clerical status from Martinez a short period before the discontinuation of his employment was announced (ibid at paras 15-17), hence the Church treated this case as what should be considered, according to the classification of the current article, a scenario of external discrimination (this step of the Church was emphasized by the dissenting judges, claiming that in such a scenario Martinez should be protected by regular labor laws, making his job dismissal illegal (see ibid at 44)).

25. Note that freedom of religion can ground kinds of discrimination that are not connected to freedom of association, which rather limit other factors such as freedom of conscience and private property claims. These categories require a different set of considerations that will not enter the current article. For an overview, see Douglas Laycock, "The WeddingVendor Cases" (2018) 41 Harv JL \& Pub Pol'y 49.

26. In Ontario Human Rights Commission v Christian Horizons, 2010 ONSC 2105 [Christian Horizons], the Ontario Superior Court of Justice decided whether this Christian organization could legitimately discontinue the employment of an employee over her sexual preferences. The Court answered this question in the negative. In the terms suggested in the current article, the Court viewed the discrimination as being external to the religious community because the organization suggested services not only for the members of the community. Therefore, the noted discrimination cannot be understood as an internal part of the religious way of life of the community. 
If the reason for granting immunity is freedom of the church, internal discrimination would be permissible; governmental meddling with the internal structure, appointments, or principles of the religious association most likely will upset both the theological and the prudential considerations encapsulated in the argument for freedom of the church noted above. However, rare cases aside, external discrimination should not be permitted as it does not touch upon the integrity and the sovereignty of the church; that is, the principle that freedom of the church aims to protect is not served by such external discrimination.

The following table succinctly summarizes the relationship of the categories introduced so far.

\begin{tabular}{|c|c|c|}
\hline $\begin{array}{l}\text { Justification for } \\
\text { immunity }\end{array}$ & $\begin{array}{l}\text { Kind of discrimination: } \\
\text { Internal }\end{array}$ & $\begin{array}{l}\text { Kind of discrimination: } \\
\text { External }\end{array}$ \\
\hline $\begin{array}{l}\text { Freedom of } \\
\text { association }\end{array}$ & $\begin{array}{l}\text { If the justification is accepted, } \\
\text { Permissible (i.e. immunity } \\
\text { should be granted) }\end{array}$ & $\begin{array}{l}\text { Even if the justification is accepted, } \\
\text { Rarely permissible (i.e. immunity } \\
\text { should not be granted) }\end{array}$ \\
\hline $\begin{array}{l}\text { Freedom of the } \\
\text { church }\end{array}$ & $\begin{array}{l}\text { If the justification is accepted, } \\
\text { Permissible (i.e. immunity } \\
\text { should be granted) }\end{array}$ & $\begin{array}{l}\text { Even if the justification is accepted, } \\
\text { Rarely permissible (i.e. immunity } \\
\text { should not be granted) }\end{array}$ \\
\hline
\end{tabular}

The table serves as a useful heuristic, ${ }^{27}$ prior to the discussion in section $\mathrm{C}$, which adds public funding as a further variable to consider. ${ }^{28}$

27. Note that the distinction between internal and external will not always be clear-cut and, indeed, courts have struggled with this distinction. One simple way to explain the distinction is to consider the standard for belonging to a community to be sharing its core beliefs and practices. If one does not share these beliefs and practices, then discrimination against them cannot be held to be internal. This criterion will solve some cases; in other cases, however, the situation may be more complicated as a person can hold a variant of the noted beliefs which would be viewed as disqualifying for membership in the association according to some members. Such cases include: Christian Horizons, ibid; Martinez, supra note 5; and Caldwell v St Thomas Aquinas High School, [1984] 2 SCR 603 [Caldwell]. In Caldwell, the Supreme Court of Canada held that a school had a bona fide occupational requirement based on Catholic practices and criteria, so it was not considered illegal discrimination (according to marital-status) to dismiss a Catholic teacher (at this public faith school) for marrying a divorced man in a civil ceremony. On the complex Canadian cases, see Kerry O'Halloran, Religious Discrimination and Cultural Context: A Common Law Perspective (Cambridge University Press, 2017) at 331-79; Megan Pearson, Proportionality, Equality Laws, and Religion: Conflicts in England, Canada, and the USA (Routledge, 2017); Benjamin L Berger \& Richard Moon, eds, Religion and the Exercise of Public Authority (Bloomsbury, 2016); Richard J Moon, ed, Law and Religious Pluralism in Canada (UBC Press, 2009). In such cases, as is suggested in section $C$ below, cost internalization might be an adequate solution.

28. To state the obvious, scholars that do not accept the freedom of association justification and/or the freedom of the church justification will reach a different conclusion and will refuse to allow the granting of immunity even in the 'internal' discrimination category. While such an approach is possible, it will collide with the view that attributes at least some importance to the justifications for immunity noted (freedom of association and freedom of the church) and will also be further away from the legal and political reality analyzed in the current article. We shall therefore assume (at the very least, for analytical clarity) that the noted justifications carry some normative weight. 


\section{B. State Funded Religious Associations: Why Public Funding Matters}

This section has two goals. First, to succinctly present the data demonstrating how widespread governmental funding of religions is in democratic countries. Second, to point to the important impact that public funding makes on considerations of the legitimate extent of the immunity thesis.

Governmental funding of religions is widespread in democratic regimes: thirtyfive countries that score 8 or above on the Polity scale-including the U.S., ${ }^{29}$ Canada ${ }^{30}$ Switzerland, Spain, and the Netherlands among others-fund religious clergy in various ways (e.g., salary, tax deductions, subsidizing their pensions, etc. $)^{31}$ Funding religious clergy makes the establishment and maintenance of religious associations less expensive and less complex than in cases where such funding is not provided. Thus, it should be understood as making membership in the funded religious associations less costly than membership in non-funded religious groups. Furthermore, a recent study has indicated that if we examine the more general category of governmental assistance to religion, we find that democratic countries almost universally provide some such support. ${ }^{32}$

This data raises the following question: what novel considerations do government funding introduce into the evaluation of the immunity thesis for religious associations that exercise internal and/or external discrimination ${ }^{33}$

29. See IRS, “Topic No. 417 Earnings for Clergy" (2020), online: https://www.irs.gov/taxtopics/ tc417. For a detailed analysis of the various ways in which religious associations in the US are supported by public funding, see Nelson Tebbe, Religious Freedom in an Egalitarian Age (Harvard University Press, 2017) at 182-97. Note, however, that the cases being discussed in this article are more explicit cases of direct funding of religious associations and activities. That said, the gap between Europe, and its established and endorsed church models, and the US separation model is being eroded. This can be seen in The American Legion $v$ American Humanist Association [2019] No 17-1717, 588 US _. This decision involved the Bladensburg Cross. The Court held that usage of public funds to maintain the Cross, which is situated on public land, did not violate the Establishment Clause. For the argument that the US is moving away from the separation model, see Richard Schragger \& Micah Schwartzman, "Religious Antiliberalism and the First Amendment" (2019) 104 Minn L Rev 1341.

30. Via, for example, direct funding of Christian faith schools, such as in Ontario. This funding, and the selective manner in which it is practiced (only Catholic schools are entitled to such funding), was the focus of two major cases: Adler v Ontario [1996] 3 SCR 609 [Adler] (which found that this policy does not violate the Canadian Charter) and Waldman v Canada [1996] Communication No 694 [Waldman], in which the UN Human Rights Committee found no legitimate justification for the noted selective funding of faith schools.

31. There are 71 countries in the Polity data set (2014) that score 8 or higher. The Polity data set ranks countries from -10 to 10 . A score of 6 and above counts as democracy. Notably, no Western democracy ranks below 8 . The threshold of 8 was preferred, to make sure that the data provided includes only well-established democracies. The data here is from the Religion and State Project, online: http://www.thearda.com/ras/.

32. See Perez \& Fox, supra note 4.

33. In some cases, the noted governmental funding is a constitutional obligation, which means that changing it might be very difficult. Such a situation was present in Adler, supra note 31 and in Waldman, supra note 31 . Both of these cases debated the legitimacy of selective funding granted to Christian public denominational schools (the noted selective funding was deemed legitimate in the former case, and illegitimate in the latter case). In the context of the current article, the goal is to reach the correct moral answer to such cases, and only at a later step to examine the actual practical steps required to enact that answer. Finally, note that Adler and 
The relevant literature on religion-state relations offers many arguments for the view that such public funding of religion is generally impermissible. In the context of the current article, we shall explore three specific reasons from this literature in order to explain (in section C) why public funding-when it is provided within a liberal democracy_narrows the legitimate domain of the immunity thesis.

First, governmental funding of religious services would create distinctions between religions that receive such funding and those that do not. This would create a hierarchy among citizens who belong to different religious groups. According to central figures of liberal thought, such as Dworkin, a state of affairs with 'two classes' of citizens simply is impermissible in liberal-democratic countries. ${ }^{34}$

Second, governmental funding of religious associations conflicts with the liberal public reason approach. This view maintains that public policies or laws should not be enacted if they are not acceptable to all persons over whom the noted rules will have authority. Religions enjoying governmental funding will struggle to elaborate reasons for that support which would be accepted by the general population (i.e. that such reasons will not be formulated in narrow theological terms acceptable solely to the believers of such religions). ${ }^{35}$

Finally, public funding of religious associations requires considerable governmental knowledge regarding these associations' needs, and this would require substantial data collection regarding the number of active believers, the centrality of specific beliefs and practices to the religious associations asking for funding, adequate knowledge regarding the geographical location of believers, and many other pieces of information. This entanglement of religion and state poses dangers for both the state and the religions involved, and there is strong support for the claim that it is unnecessary for the flourishing of religious activity. ${ }^{36}$

Waldman were focused on discrimination between denominations, not on discrimination conducted by religious associations against individuals.

34. As Dworkin writes: "political decisions must be, so far as possible, independent of any particular conception of the good life ... since the citizens of a society differ in their conceptions, the government does not treat them as equals if it prefers one conception to another": Ronald Dworkin, "Liberalism" in A Matter of Principle (Harvard University Press, 1985) 181 at 191. The endorsement of a religion, as Justice O'Connor of the US Supreme Court argues in a wellknown concurring opinion, "sends a message to non-adherents that they are outsiders, not full members of the political community, and an accompanying message to adherents that they are insiders, favored members of the political community": Lynch v Donnelly (1984), 465 US 668 at 688. TM Scanlon, writing on inequality generally, summarizes this point adequately: "providing unequal levels of these services to different groups, without some special justification, violates a general (comparative) requirement of equal concern. In many such cases, these differences in treatment may be explained by a background of racial prejudice and discrimination, which is morally objectionable": TM Scanlon, Why Does Inequality Matter? (Oxford University Press, 2018) at 16.

35. For an overview of the public reason literature, see Jonathan Quong, "Public Reason" in Edward N Zalta, ed, The Stanford Encyclopedia of Philosophy (2017) (Spring 2018 Edition), online: https://plato.stanford.edu/archives/spr2018/entries/public-reason/; Cécile Laborde, Liberalism's Religion (Harvard University Press, 2017) at 69-112.

36. The literature on the demerits of the entanglement of religion and state for both the state and the specified religions is wide. See, e.g., Thomas Lindsay, "James Madison on Religion and Politics: Rhetoric and Reality" (1991) 85:4 Am Political Science Rev 1321; Nicholas Patrick Miller, The Religious Roots of the First Amendment: Dissenting Protestants and 
Considered together, these three claims support the larger argument that governmental funding of religions is impermissible in liberal democracies. However, our interest in this article lies with governments and legal systems that do permit and exercise such support. This does not mean that these arguments should not be taken as serious and significant warnings or pieces of advice, even though we limit ourselves to religion-state arrangements that stop short of a full-fledged ban on state funding of religions. Rather, the current article explores how such arguments imply limitations on the ways such funding can be carried out. To put this point differently: governmental funding of religious associations should be carried out in ways that would minimize the troubling outcomes of the three considerations noted above, if at all possible. ${ }^{37}$

We hence turn to section $\mathrm{C}$, which presents a multi-variable test aiming to evaluate cases in which governmental-funded religious associations request to gain immunity from non-discrimination rules.

\section{A Multi-Variable Test: Governmental-Funded Religious Associations and Immunity}

Suppose that religious association A receives funding from the government, and that this association enacts discriminatory practices that allow men but not women to be appointed as religious clergy. Further, assume that this association also discriminates in its external affairs through its employment policy vis-à-vis non-members, in that it only employs men (say, as janitors in the association's buildings). Let us assume that the association is challenged on both internal and external discriminatory norms. How should a liberal democratic theory approach such a case?

This scenario differs from the general topic of governmental funding of religious associations discussed in section $\mathrm{B}$, as in this scenario the religious association requests both governmental funding and immunity from non-discrimination rules. This additional step should not be taken lightly. Discrimination is banned by many human rights instruments. ${ }^{38}$ While there is a lively scholarly debate regarding

the Separation of Church and State (Oxford University Press, 2012). Interestingly, there have been attempts to argue for the merits of governmental funding of religion, for example, as a way to enhance a given civil society. See Richard Traunmüller \& Markus Freitag, "State support of religion: Making or breaking faith-based social capital?" (2011) 43:3 Comp Politics, 253. However, the enhancement argument does not necessitate governmental funding. Indeed, religious pluralism thrives in countries such as France, which does not fund religious associations. See Pew Research Center, "Global Religious Diversity" (2014), online: http://www. pewforum.org/2014/04/04/global-religious-diversity/; Roger Finke \& Rodney Stark, "Religious Choice and Competition" (1998) 63:5 Am Sociological Rev 761.

37. Note, however, that the topic of permissible funding of religious services is wide. The topic of the current article is how governmental funding of religious services influences the right to immunity from non-discrimination rules, a narrower topic.

38. See, e.g., Part II, Article 2 of the International Covenant on Civil and Political Rights (1966), which states: "Each State Party to the present Covenant undertakes to respect and to ensure to all individuals within its territory and subject to its jurisdiction the rights recognized in the present Covenant, without distinction of any kind, such as race, colour, sex, language, religion, political or other opinion, national or social origin, property, birth or other status." See Bielefeldt et al, supra note 9 at 309-36 for other examples. 
the specific reason (or normative grounds) following which discrimination is impermissible in democratic countries, ${ }^{39}$ there is a wide consensus in law (and morality) that discrimination - especially if based on protected characteristics or attributes such as race, ethnicity, gender, religion, sexuality, and several others-is simply impermissible. Using public, governmental funds in order to carry out activities that are discriminatory, such as forcing one to leave a workplace because of sexuality or religion (as in Martinez), is generally an impermissible act. In order to legitimize it, some forceful justification must be presented for both the discriminatory act and for the further step of making the taxpayer fund such discriminatory practices through public support of religious groups.

As discrimination is impermissible in democratic societies, any policy that entails governmental funding of religious associations that enact such discrimination qualitatively differs from routine disagreements regarding policies such as taxation, education, and so on. Funding policies that have disparate implications for different parts of the citizenry are part and parcel of regular democratic policies; while there are winners and losers for many policies, no inherent violation of rights occurs at such occasions. In the case at hand, the taxpayer will be supporting overtly discriminatory acts. Any justification suggested for a policy in which the government applies tax revenues in order to support such associations will have to be rather compelling.

One option is simply to reject governmental funding of religious associations that discriminate. An example is the Bob Jones decision of the U.S. Supreme Court, in which Bob Jones University (a private, evangelical university in South Carolina) was denied a tax exempt status given its racial, discriminatory practices. ${ }^{40}$ According to scholars, ${ }^{41}$ characteristics of gender, sexuality, and religion are entitled to similar protections as the Bob Jones case asserted for racial characteristics.

As will be further elaborated as we present the multivariable test, the current article avoids the expectation that religious groups will abandon their principles when faced with the danger of losing all governmental funding. Rather, where possible (but excluding racial cases), such religious groups should internalize the cost of discrimination as this arrangement allows them to remain loyal to their

39. Three prominent arguments are: that discrimination is a severe offence against the dignity of the person being discriminated (see Denise Réaume, "Dignity, Equality and Comparison" in Deborah Hellman \& Sophia Moreau, eds, Philosophical Foundations of Discrimination Law (Oxford University Press, 2013) 7); that discrimination is a violation of a comparative equality obligation in the sense that person A, who is similarly situated to person B, is deprived of a good allocated to B (see Deborah Hellman, "Equality and Unconstitutional Discrimination" in Deborah Hellman \& Sophia Moreau, eds, Philosophical Foundations of Discrimination Law (Oxford University Press, 2013) 51); and that discrimination deprives a given person from the liberty to do X (see Sophia Moreau, "In Defense of a Liberty-based Account of Discrimination" in Deborah Hellman \& Sophia Moreau, eds, Philosophical Foundations of Discrimination Law (Oxford University Press, 2013) 71).

40. Bob Jones University v United States (1983), 461 US 574. As indicated by Justice Burger at 604: "the Government has a fundamental, overriding interest in eradicating racial discrimination in education .... That governmental interest substantially outweighs whatever burden denial of tax benefits places on petitioners' exercise of their religious beliefs."

41. See the sources discussed in note 39 . 
own principles. In order to explain this position, we contrast it with two other options, as follows. ${ }^{42}$

First, it is possible to suggest that direct governmental funding to religious associations presumes that such associations will converge with the liberal democratic norms that shape mundane state organizations (the IRS, or any governmental ministry). This view means that, eventually, religious associations will cease to be as they will be gradually subsumed within the apparatus of the bureaucratic state. A dissenting judge in the JFS case, Lord Roger, effectively articulated the counter claim to the 'convergence' position, and insisted that funded faith schools must be permitted to retain their own membership criteria in admission policies if they are to remain proper faith schools: "The decision of the majority means that there can in future be no Jewish faith schools which give preference to children because they are Jewish according to Jewish religious law and belief." ${ }^{43}$

Second, fully funded immunity is an option whereby religious associations receive governmental funding yet retain full immunity from non-discrimination rules both internally and externally. ${ }^{44}$ This option is to be rejected immediately as it ignores the harms of discrimination that are impermissible in democratic societies. Note that our focus here is not merely the topic of governmental funding provided to religious associations (see section B), rather it is the recognized right of individuals not to be discriminated against by the government. ${ }^{45}$

We turn, therefore, to a multivariable test that aims to create a balance between the autonomy of religious associations on the one hand, and the protection of

42. Some religion and state scholars would wish to simply dismiss the entire scenario as impermissible to begin with. No funding whatsoever from public, governmental sources should ever be directly provided to religious associations. Note that the current article does not directly disagree with this position. Rather, it simply asserts that it cannot be applied (at least not immediately) to religion-state systems that adopt an established church, endorsed church or supported religions models.

43. JFS, supra note 6 at para 225. Also see Martha C Nussbaum, "A Plea for Difficulty" in Susan Moller Okin, ed, Is Multiculturalism Bad for Women? (Princeton University Press, 1999) 105 at 114. Nussbaum argued that: "it seems illiberal to hold that practices internal to the conduct of the religious body itself- the choice of priests, the regulations concerning articles of clothing - must always be brought into line with a secular liberal understanding of the ultimate good."

In the context of the current article, which analyzes existing cases of governmentally funded religious associations, discrimination should be precisely considered. That is, persons who are discriminated against and might be entitled to compensation here (see section C) are only those for whom a non-discrimination outcome is conceivable. For example, in JFS, the candidate is considered Jewish under some variants of Judaism, making a non-discriminatory outcome conceivable. A Catholic student wishing to enter the JFS would be rejected as well, though this will not be counted as wrongful discrimination. This 'narrow discriminatory' criterion builds upon work in the methodology of the social sciences. See, e.g., James Mahoney \& Gary Goertz, "The Possibility Principle: Choosing Negative Cases in Comparative Research" (2004) 98:4 Am Political Science Rev 653.

44. This was the position of the Catholic Church in Martinez. See Martinez, supra note 5 at 32.

45. This point reflects development in administrative law where norms and rules that are applicable to the government are gradually applicable to hybrid institutions and also private institutions, especially in the era of privatization. See Jack M Beermann, "Administrative-Law-Like Obligations on Private[ized] Entities" (2001) 49 UCLA L Rev 1717; Daphne Barak-Erez \& Oren Perez, "Whose Administrative Law is it Anyway? How Global Norms Reshape the Administrative State" (2013) 46 Cornell Int'l LJ 455. 
important civil interests on the other hand. The guiding logic here mirrors Locke's attempt to create a clear distinction between church and commonwealth; ${ }^{46}$ while public funding of religion obviously complicates this Lockean political structure, any other approach will bring about a dangerous conflation of church and state. Put differently, the balanced, multivariable test attempts to prevent a situation in which public funding of religion becomes the means for governmental managing of a church, or the means for the church to gain political position and influence. Indeed, the explicit language of Martinez seems to suggest this logic: "In the present case, this balancing exercise concerns the applicant's right to his private and family life, on the one hand, and the right of religious organisations to autonomy, on the other." 47

Three variables in this 'test' are internal to the associations' structure and norms: (1) the centrality of the religious norm to the funded religious associations, (2) the kind of violation of non-discrimination rules (internal or external discrimination), and (3) the willingness of the religious association to internalize the cost of the discrimination. Two variables are external to the association: (1) the quantity of funding, and (2) the process in which potentially competing religious associations can become eligible for recognized status that leads to state funding. Each variable will be succinctly presented and analyzed in subsection C.1. Once the five variables are outlined, we shall comment on Martinez in order to demonstrate the suggested multi-variable test's utility (subsection C.2). ${ }^{48}$

\section{C.1. Presenting the variables}

\section{(I) The centrality of the religious norm to the funded religious associations}

In cases that involve discrimination conducted by publicly funded religious associations, the harm to the public interest is clear. Such discrimination severely

46. See Locke, supra note 13 at 6-9.

47. Martinez, supra note 5 at para 123. Compare Tariq Modood, "State-Religion Connections and Multicultural Citizenship" in Jean L Cohen \& Cécile Laborde, eds, Religion, Secularism, and Constitutional Democracy (Columbia University Press, 2015) 182-203; Jacob T Levy, Rationalism, Pluralism, and Freedom (Oxford University Press, 2015).

48. Note that the multi-variable test stems from the complexity of the phenomenon it aims to analyze and evaluate. While the problem of giving adequate weight to each variable remains, it is difficult to see a simple, one-variable approach to the phenomenon at hand. The current research follows the pluralist approach to political and legal problems. In political theory, see Joseph H Carens, "Two Conceptions of Fairness: A Response to Veit Bader" (1997) 25:6 Political Theory 814 at 818; in legal theory, see Kent Greenawalt, Religion and the Constitution, Volume 2: Establishment and Fairness (Princeton University Press, 2008). For a critical exploration of this pluralist approach to religious freedom disputes, see Nelson Tebbe, "Religion and Social Coherentism" (2015) 91 Notre Dame L Rev 363. Perhaps it is important to note that indeterminacy is widespread in legal and normative reasoning (i.e. that there are cases in which the rules of a legal system and/or a normative system allow for several different outcomes, usually within a given frame or range of options), leaving some space for discretion, political procedures, and/or simple persuasion. On indeterminacy in law, see HLA Hart, The Concept of Law (Oxford University Press, 1961) at 119, 123-25. In normative theorizing, see Amartya Kumar Sen, The Idea of Justice (Harvard University Press, 2009) at 1-15. 
damages the interests of those immediately discriminated against. Given that discrimination based on protected attributes is impermissible in democratic countries, some other value or public policy goal is needed to legitimize such harms. If a central belief or practice of the religious association is at stake (in the sense that it leads to the noted discrimination), that core value would be the ability of the members of the association to continue to practice their religious belief; this justification proves less compelling if the discriminatory belief/ practice is peripheral to the association's religious faith. Adequately satisfying this variable presents a non-trivial challenge for a religious association that wishes to maintain immunity while enjoying public funding, as such a claim ('this practice is central to our faith') would have to satisfy some degree of public scrutiny by external judges or public officials who will likely rely on scholarly and expert testimonial concerning the history of this group's religious practices. ${ }^{49}$

Three points about this variable are important. First, presenting the core ideas of a given religion for public scrutiny might in itself be an unpleasant experience for this community, especially as this scrutiny will critically distinguish central and peripheral practices and beliefs of this group. ${ }^{50}$ Second, the contours of immunity will narrow as the evidence that establishes the centrality of a belief or a practice becomes explicit; religious associations that do not receive public funding and wish to claim immunity from non-discrimination rules have (at least in the U.S.) simply to maintain that some issue is the association's internal affair. This is succinctly articulated by Laycock: "when a church does something by way of managing its own internal affairs, it does not have to point to a doctrine or a prohibition or a claim of conscience in every case. It can make out a good church autonomy claim simply by saying that this is internal to the church. This is our business; it is none of your business." ${ }^{, 51}$ Third, the centrality variable has met some resistance that needs to be considered here, as follows. Courts are at times unwilling to determine the 'centrality' of a given practice to a given religion. In Syndicat Northcrest $v$ Amselem, ${ }^{52}$ for example, the Supreme Court of Canada-in their attempt to understand the scope and shape of the requirement in Jewish law of building a Sukkah - preferred a narrower demand of sincerity, good faith, and non-fictitiousness. In a similar pattern of resistance to the centrality variable, scholars warn that such demands might create an incentive for the relevant group to label each and any religious practice as central. ${ }^{53}$

49. Compare Laborde, supra note 35 at 160-96.

50. See Avigail Eisenberg, Reasons of Identity: A Normative Guide to the Political and Legal Assessment of Identity Claims (Oxford University Press, 2009) at 91-118. Eisenberg makes the distinction between central and peripheral norms or practices of a religious association and raises the issue of the proper decision-making body (i.e. 'who decides'?). However, in the scenario in front of us, the relevant group enters willingly to a situation in which this issue is raised.

51. Laycock, supra note 7 at 254.

52. 2004 SCC 47.

53. See Jobani \& Perez, supra note 18 at 143-76; Ayelet Shachar, Multicultural Jurisdictions: Cultural Differences and Women's Rights (Cambridge University Press, 2001) at 35-37. 
However, how persuasive are such criticisms? To begin, courts, at times, have found indirect ways to determine centrality. For example, in Caldwell, the Supreme Court of Canada found marital status of an employee to be a part of bona fide occupational requirement and allowed the employee's dismissal. ${ }^{54}$ It is not hard to see that this is but a different way to determine centrality.

Furthermore, most of the noted criticisms regarding the 'centrality' criterion are typically raised in a different context, where the requests for religious group autonomy are made by groups not directly supported by governmental funding, and in which discrimination is not involved. Rather, the requests are usually in the form of an exemption from generally applicable laws, such as-in the Amselem case-a building related by-law. These two added variables (discrimination and direct governmental funding) bring about the centrality demand. Removing the centrality demand and merely keeping the sincerity demand will neglect the seriousness of the harm caused by the noted discrimination and will neglect the violation of rights caused to the victims of said discrimination.

Finally, the worry that the centrality demand would simply motivate groups to 'label' each and every practice as central can be dismissed, after due consideration, as there are many ways to examine centrality without depending on the self-reporting of the group. Historians, anthropologists, and religious scholars can all provide their dis-interested opinions on the matter. ${ }^{55}$

\section{(II) The kind of violation of non-discrimination rules}

When examining both internal and external violations of non-discrimination rules, being consistent with the analysis above (section A), external discrimination is found inconsistent with the assumptions that accompany receiving public funding except in rare cases. ${ }^{56}$ Internal discrimination can be consistent with public funding as, without this allowance, religious associations will no longer be able to maintain their own principles (as discussed in section A above). However, even when the noted discrimination is internal, it must be cumulative with the centrality variable: this is a key difference that receiving public funding makes. If a religious association that does not rely on public funding conducts internal discrimination in a peripheral practice or belief, it is the association's

54. Caldwell, supra note 27.

55. Several scholars have suggested tests aiming to examine the legitimacy of exemptions/ immunity. See, e.g., Nick Martin, "Exemptions, Sincerity and Pastafarianism" (2019) J Applied Philosophy, online: https://doi.org/10.1111/japp.12386 (debating consistency versus sincerity); Yuval Jobani \& Nahshon Perez, "Toleration and illiberal groups in context: Israel's ultra-orthodox "society of learners"' (2014) 19:1 J Political Ideologies 78 (examining cases of misrepresentation of a community tradition by the same community).

56. This conclusion, as explained above, is valid even when the religious association is funded only via the contributions of the members. Receiving governmental funding reinforces this conclusion, as discrimination is a socially undesirable phenomenon and there is no reason to assume that it should be supported by the taxpayer. 
own business (and the association's own reputational hazard) ${ }^{57}$ and its immunity should probably be maintained.

However, receiving public funding does mean that public interests enter the picture more forcefully than scenarios in which religious associations are funded by the contributions of their members. As the public has a distinct interest in upholding nondiscrimination norms and rules, a funded religious association must demonstrate the centrality of the practice or belief that grounds said internal discrimination if it wishes to maintain immunity. In doing this, the association must demonstrate that an important interest of theirs is at stake while also respecting the broader public's interest in nondiscrimination rules. A peripheral religious practice of the group is not powerful enough to counter the public's interest in nondiscrimination rules; disrupting that practice will not substantially affect the ability of the association's members to maintain their religious beliefs.

To conclude, the additional hurdle of 'centrality,' put in the way of governmentally funded religious associations who wish to internally discriminate while being immune from the broader non-discrimination norms, is the 'cost' of receiving public funding.

\section{(III) The willingness of the religious association to internalize the cost of discrimination}

Requiring that a religious association — rather than the employee-internalize the cost of discrimination is one method for resolving employment discrimination based on religious doctrine at governmentally funded religious associations. ${ }^{58}$ Cost internalization means that the association will bear the financial costs resulting from the noted discrimination. In Martinez, for example, the Church could have borne some financial burden to ease the loss of income and the frustration caused by his inability to continue his life plan, brought about by the non-renewal of Martinez' teaching position. This can include, for example, compensating the employee, even if the association would not be required to do so by the ordinary relevant laws. ${ }^{59}$ The logic here stems from two considerations: first, if cost internalization is exercised by the association, the fact that an employee has exited from the religious association remains a theological issue, rather than a civil issue. This prevents a scenario in which financial necessity leads an employee of the association to remain a religious member in violation of some core belief held by the employee. Put differently, if cost internalization is exercised, then the

57. Richard A Posner, Economic Analysis of Law (Wolters Kluwer Law \& Business, 2011) at 915-17.

58. Note that this variable is suitable in cases where the discrimination can be understood (at least in part) as a labor-market dispute, rather than a case which is mainly a religious dissent scenario, which will be discussed in section C.1.V below.

59. In Martinez, supra note 5 at para 19, the Diocese argued that: "[The applicant]'s personal and employment situation has also been taken into account, since [he] is entitled to receive unemployment benefit for at least a year and a half." The cost internalization variable demands further activity from the funded religious association if it wishes to maintain immunity. 
theological and perhaps social cost of exit for the individual remains, but there is no additional material burden. ${ }^{60}$

Second, since the scenarios analyzed in the current article are those in which the government funds a religious association, unless the religious association accepts some cost-internalization framework, the association shifts the cost of the discrimination to the tax payer-in that they fund the general activities of the association - and to the victim who loses both their membership in the association and their livelihood. This provides additional incentive for demanding that the association bears some of the cost of their discriminatory actions, rather than shifting the entire cost to the general public and/or the individual member who already bears burdens from the religious association's discrimination.

This condition is cumulative with the two previous variables: centrality and the kind of discrimination. To gain immunity from nondiscrimination rules, a governmentally-funded religious association must demonstrate that the practice or belief grounding the noted discrimination is central, that the discrimination is only applied 'internally,' and that some form of cost internalization is in place.

\section{(IV) The quantity of funding}

This variable aims to link the level of governmental support that is granted to a given religious association directly to the extent of legitimate claims for immunity that it can exercise. The logic here is simple: the extent of immunity from non-discrimination rules decreases as the amount of funding increases. The rationale is that receiving funding to cover the costs of a large percentage of the association's activity implies that the state basically operates the religious

60. See Barry, supra note 13 at 150-54 for an interesting discussion of exit costs. Barry distinguishes between exit costs that are 'intrinsic,' 'associative,' and 'external.' Intrinsic costs are those that cannot be avoided unless the group is destroyed (e.g., the right of a religious association to excommunicate a dissenter). Associative costs are mainly social (e.g., the members of a certain religious association cease to associate with an ex-member). External costs are those costs that impose material losses on exiting members, beyond any religious or social issues. These may occur if, for example, a former community member is fired after being excommunicated because his employer is still a member of the religious association and does not want any connection with ex-members. Barry concludes that intrinsic costs are inevitable if we wish to respect freedom of association and freedom of religion. He regards associative costs as an unfortunate social phenomenon, but he concludes that the government cannot prevent them. Finally, he holds external costs as impermissible restrictions put on the right of exit. Scholars have suggested, in response to cases involving external costs, that imposing 'exit funds' on associations that create such costs will offset the costs imposed on the exiting members; this will, by extension, ensure that exiting remain a theological issue. See Nahshon Perez, "Should multiculturalists oppress the oppressed? On religion, culture and the individual and cultural rights of un-liberal communities" (2002) 5:3 Critical Rev Int'l Social and Political Philosophy 51; Jeff Spinner-Halev, Surviving Diversity: Religion and Democratic Citizenship (The Johns Hopkins University Press, 2000) at 77-81). It is possible to go further than the current article suggests and to use such economic methods to achieve further goals. For example, by eliminating governmental aid to religious associations that discriminate on the basis of gender and race, in this way, a legal system could try to reduce or even eliminate discrimination. See (in the US context) Caroline Mala Corbin, "Expanding the Bob Jones Compromise" in Austin Sarat, ed, Accommodation and Its Limits: Legal Responses to Religious Practices in the United States (Cambridge University Press, 2012). 
association to the extent that they are virtually indistinguishable. ${ }^{61}$ If the religious association and the state are indistinguishable, the association loses its special religious protection and becomes a state organ which has to meet all mundane non-discrimination rules. While this may seem like a technical variable, it arises from complex and diverse data regarding the measure of public support granted to religious associations. ${ }^{62}$ Policies here vary to a large extent, so ignoring the proportion of funding might lead to an overly broad category of 'support for religion' which is insensitive to this wide difference between cases. The rule that seems most appropriate here is the following: the higher the funding made available to a religious association, the weaker the case for funded immunity becomes. This principle holds even if each of the previous three variables are met. The reason is that the previous variables fit cases in which religious associations are being discriminatory, but cases of full governmental funding imply that the organ enacting the discrimination is the state. ${ }^{63}$

61. Note that a religious association fully funded by the government cannot easily claim the two justifications for immunity noted in section A. Freedom of the church is lost as full funding by the government means that considerable control is moved from the association to the state. Freedom of association is lost, or at least compromised, as decision-making and autonomy regarding the nature of the association is relocated to the government, which employs the clergy. There are cases of public-private partnership in which the source of funding is public, yet the organization is quasi-private. However, such arrangements are usually not exempted from non-discrimination rules or other norms of public law. Put differently, if a fully funded religious association wishes to claim that it is independent in its decision-making structure, it needs to demonstrate this point, for example, via a demonstration of its autonomy while appointing clergy. This counter-intuitive situation requires proof, and the burden of proof is placed on the publicly funded religious association who wishes to maintain immunity. For further analysis of private-public partnerships, see Martha Minow, "Partners, Not Rivals: Redrawing the Lines between Public and Private, Non-Profit and Profit, and Secular and Religious" (2000) 80 Boston University L Rev 1061; Orr Karassin \& Oren Perez, "Shifting Between Public and Private: The Reconfiguration of Global Environmental Regulation" (2018) 25 Ind J Global Leg Stud 97.

62. See Francis Messner, ed, Public Funding of Religions in Europe (Routledge, 2016); Eurostat, "Government expenditure on recreation, culture and religion" (2020), online: https://ec.europa. eu/eurostat/statistics-explained/index.php/Government_expenditure_on_recreation,_culture_ and_religion\#Expenditure_on_.27recreation.2C_culture_and_religion.27.

63. See Jobani \& Perez, supra note 18 for a recent example from the case of the Women of the Wall (the Jewish feminist organization attempting to gain the authorities' permission to pray according to their manner at the Western Wall) which might help to clarify this point. In late 2015, members of the Women of the Wall, via the Center for Women's Justice - an Israeli NGO that deals with issues pertaining to women's equality (broadly conceived) in Israeli societybrought a petition to the Israeli Supreme Court. In this petition, it was argued that the ban against bringing Torah scrolls to the women's section of the Wall is illegal. They also brought a civil suit against the Rabbi of the Wall that sought compensation for what they claimed to be gender-based discrimination (a copy of the petition is on file with the author; a decision still pending). In both the petition to the Supreme Court and in the civil lawsuit, a central part of the argument was that the Rabbi of the Wall - a state employee-functions as a state agent. As such, the law clearly forbids him from discriminating on the basis of gender. The Women of the Wall maintain that the Rabbi's actions violate Israeli non-discrimination laws that apply to civil servants and state employees, and hence take it for granted that the Rabbi's appointment within the state apparatus supersedes his religious identity and functionality. 
(V) The process in which potentially competing religious associations can become eligible for recognized funded status

Some cases of internal discrimination conducted by religious associations involve not just labor-based discrimination but also the restraining of religious dissent within the association. In Martinez, for example, Martinez was a member of a movement within the Catholic Church that advocated for priests to be free to marry and have children. ${ }^{64}$ Since this movement attempts to bring about a doctrinal change within Catholicism, ${ }^{65}$ Martinez involves a theological disagreement in addition to the labor dispute.

In cases where internal discrimination within governmentally funded religious associations at least partially reflects religious schisms (actual or in process), the process through which dissenting groups themselves can become funded associations is a relevant variable. If the government has a procedure that allows for religious associations to gain recognition and funded status, the sensible solution is to allow for the religious association to maintain immunity and for dissenting individuals to establish a new religious association that would gain the authorities' recognition and support. This follows from the foundational principles of the immunity thesis: if autonomy of religious associations is a desirable goal (given the justifications of freedom of association and freedom of the church surveyed in section A), then it would be wrong to allow religious dissenters to compel a given religious association $\mathrm{A}$ to abandon its principles and to include dissenting practices. Indeed, if the dispute between the funded religious association and the discriminated individual is not (mainly) about this person's wish to be employed, but rather pertains to some theological disagreement, then the solution should be sought in the religious sphere rather than in employment laws. The policy response should be to encourage the dissenting member to join (or try to establish) a different religious association that enjoys state funding. ${ }^{66}$ This variable, notably, is disconnected from the first three-as centrality, kind of discrimination, and cost internalization all apply to scenarios of labor-based disputes - as religious dissent differs from discriminatory employment.

As a final comment, this variable at times concerns scenarios in which a governmentally funded religious association enjoys a status similar to that of a monopoly in economics (i.e. a sole provider of religious services, protected by legal barriers that prevent competitors from entry into the relevant sphere of activity). In such cases, if the government does not provide a way for dissenting

64. The "Movement for Optional Celibacy." See Martinez, supra note 5 at para 25.

65. Richard A Schoenherr, Goodbye Father: The Celibate Male Priesthood and the Future of the Catholic Church (Oxford University Press, 2004).

66. Religious disputes regarding church property or appointments (in US jurisprudence) that at times reach civil courts have followed a pattern whereby the courts usually either accept the church-established procedures for decision-making or apply non-religious standards to such disputes with the explicit goal of avoiding civil intrusion on the autonomy of churches (i.e. a 'hands off' approach). Arguably, the fact of public funding should not change this pattern. On church disputes and civil courts, see Kent Greenawalt, "Hands Off! Civil Court Involvement in Conflicts over Religious Property" (1998) 98:8 Columbia L Rev 1843. 
(or any other) religious associations to win recognition and public-funding, the religious association that functions as a monopoly has a much weaker claim to immunity. These circumstances would make the association so similar to the state that it compromises its character as a religious association. While this may seem like an unfair conclusion, as it holds the religious group liable for a governmental decision, this is in fact not the case: such close cooperation between religion and the state, under regular circumstances, implies that the religious association has lost its autonomy. Once absorbed into the state governance apparatus, the original reasons for granting immunity are irrelevant. Put differently, in cases in which the government provides one religion with a monopoly status, the main concern is preventing governmental abuse of power against the co-opted religion and against nonmembers, through a religious proxy, on religious grounds, rather than worries regarding harms to freedom of association. ${ }^{67}$

\section{C.2. The multivariable test and funded religious associations: a comment on Martinez}

Now that we have outlined the variables of our test, we can use them to comment on Martinez. While a full-fledged analysis of this complex case is beyond the scope of this article, this subsection can briefly demonstrate the utility of the proposed multivariable test. ${ }^{68}$ Such multivariable tests should not be expected to bring about only one specific outcome, ${ }^{69}$ instead they should help navigate the complex details of cases that necessitate maintaining, as much as possible, the autonomy of a religious association and protection of individuals from discrimination. That is, as much as possible, the test should aim to maintain the distinction between civil and religious issues.

To remind, this case involved the discontinued employment of a Catholic teacher. While employed by the state (Spain) in a public school, his position as a teacher of religion required the approval of the Catholic Church. This approval was withheld-even though his teaching evaluations were impeccable-after it became known that, while officially a priest, he was married with children. In a 9-8 ruling the ECHR held in favour of the Catholic Church, concluding that his dismissal was legitimate. Let us examine this case in light of the multivariable test. The centrality of celibacy for determining membership in

67. The dangers involved for both the noted religion and for civic equality in cases in which a given religion is co-opted by the government are well discussed in the literature. On the danger to civic equality, see Abdullahi Ahmed An-Na'im, Islam and the Secular State (Harvard University Press, 2008). On the resulting corruption of religion, see Andrew Koppelman, Defending American Religious Neutrality (Harvard University Press, 2013) at 46-77.

68. Note that the utility of the test requires that a degree of discretion is granted to those attempting to apply it to cases as they will have to decide how to classify complex cases according to the variables. As the classic aphorism by Justice Holmes (dissenting) indicates: "General propositions do not decide concrete cases" (Lochner v New York (1905), 198 US 45 at para 76).

69. See Joseph H Carens, Culture, Citizenship, and Community: A Contextual Exploration of Justice as Evenhandedness (Oxford University Press, 2000) at 7. 
the clergy of the Catholic Church was immediately recognized by the judges in Martinez,${ }^{70}$ and hence-with this variable ('centrality') satisfied - the first requirement for immunity was met.

Classifying Martinez as either a scenario of internal or external discrimination is much more difficult, and this is arguably what created the noted 9-8 split at the ECHR. Here, the utility of the multivariable test is demonstrated in its ability to process the case in each interpretation. If this is a case of external discrimination (as the dissenting judges in Martinez argued), the discontinuation of his employment was an impermissible act that should have been rectified. Put simply, the Catholic Church should not have control over the employment of non-members working for the government.

If this was a case of internal discrimination, as the majority of judges argued - that the case involves internal disagreement among clergy regarding some religious doctrine (in this case, celibacy of Catholic priests) - the court considered the proper remedy to be Martinez exiting the Catholic Church, which also implies the discontinuation of his teaching position.

The current article disagrees, even when the case is viewed as an instance of internal discrimination, since Martinez' teaching position was funded by the tax-payer rather than by the religious association. This means that for the discontinuation of employment to be legitimate, as explained above, three cumulative conditions must be met: the centrality of the act or belief for the association, the internal nature of the discrimination, and the internalization of costs by the relevant religious association. Assuming that the first two conditions have been met, we turn to this third condition.

The goal of the cost internalization variable is to verify that no member of the governmentally-funded religious association suffers from internal discrimination while being unable to exit the association due to financial necessity. In Martinez rescinding Martinez's status as a priest (in 1997) also cost him his job. This means that the Catholic Church imposed material costs, beyond religious or social costs, on the exiting Martinez; they also shifted the cost of his employment away from its own resources and placed it on the general taxpayer. This is worryingly close to creating economic duress to force one to conform to religious principles that they do not espouse; accepting specific religious values is directly connected to their livelihood, and the duress caused by holding a dissenting view is wholly financed by the general taxpayer. In order to legitimize the termination of Martinez's employment, the Catholic Church must internalize the cost of his de facto firing to some extent. At the very least, the Church should offset the financial implications of his firing for a reasonable period of time. Otherwise, the taxpayer will be complicit in causing religious/economic duress biased in favor of the Catholic Church.

This suggestion does not require that the religious association waives governmental funding. Rather, the association would be required only to offset the cost

70. As put by the judges, the celibacy standard is part of the "applicable provisions of canon law" (Martinez, supra note 5 at para 119). Also see ibid at paras 119-22 generally. 
levied on the fired employee. This means that the religious association can maintain its internal structure, choice of clergy, membership criteria, and remain loyal to its own religious principles. The cost internalization criterion is structured with precision: it offsets only those costs levied on the individual that are not theological or social, namely the material costs connected to the job termination of the exiting individual.

As indicated above, the cost internalization condition is cumulative with the two previous conditions: in order for the discontinued employment of Martinez to be legitimate, it must be demonstrated that the discriminatory religious norm (celibacy in this case) is central, that the discrimination is internal, and that the relevant religious association (the Catholic Church in this case) is willing to internalize some portion of the relevant cost of the discriminatory act. Therefore, according to the multi-variable test, Martinez' dismissal was not legitimate as the third variable (cost internalization) was not met.

Quantity of funding; under the conditions of the special agreement between Spain and the Holy See, the public taxpayer funds the salary of teachers of religion, yet their identity must be acceptable to the Catholic Church. ${ }^{71}$ Hence, this case involves full public funding of this religious/public post which, as explained above, means that this religious association's legitimate claim to immunity is diminished. The fact of full governmental funding serves as additional justification for the triggering of the cost internalization variable that aims to offset the further cost that this religious discrimination imposes on Martinez and the general taxpayer. The religious association must adopt such cost internalization in order to maintain that the disagreement is purely religious since the material aspects would be offset.

Finally, access to a recognized, funded religious association status. If Martinez is held to be a religious dissent case (as the majority of judges thought), the government can assess the feasibility (number of adherents, funding, etc.) of expanding its religious education policy to further groups in a quasi-evenhanded, or multiple-establishments manner. ${ }^{72}$ This option would advance, or protect, the two key goals of maintaining the autonomy of religious associations and protecting the civil interests of Martinez and other dissenting religious individuals. As this option is very complex from an institutional perspective (and is not currently

71. See $i b i d$ at 3.

72. For evenhanded schemes in religion-state relations, see, e.g., Carens, supra note 70; Jobani \& Perez, supra note 18 at 102-42. Evenhandedness, non-preferentialism, or multiple establishments are explained by Laycock and Levy, in the US context. Laycock states: "The claim is that the framers of the religion clauses intended a specific meaning with respect to the ... establishment clause: government may not prefer one religion over others, but it may aid all religions evenhandedly" (Douglas Laycock, "'Nonpreferential' Aid to Religion: A False Claim About Original Intent" (1986) 27 Wm \& Mary L Rev 875 at 877). Levy offers a similar definition: “... the legislative history of the clause ... prove an intent to impose upon the national government merely a ban against aiding an exclusive or preferential establishment, which results in their conclusion that government assistance to religion generally, without a hint of discrimination, would not violate the establishment clause" (Leonard W Levy, The Establishment Clause: Religion and the First Amendment (University of North Carolina Press, 1994) at 113). Both Laycock and Levy strongly reject non-preferentialism. 
available in Spain), the above-mentioned cost-internalization option is more feasible as a solution to cases such as Martinez.

Notably, the multivariable test is compatible with both the cost internalization and the so-called multiple establishments options; hence, it outlines varied legal and policy responses that aim to maintain the core goal of distinguishing between church and state. Indeed, both approaches aim to enable governmental funding for religious activities with minimal implications for civil and occupational interests. $^{73}$

\section{Conclusion}

This article aimed to respond to the following question: in what way, if at all, does receiving public funding impact religious associations' presumed right to immunity from non-discrimination rules? The answer is that receiving governmental funding narrows the extent of immunity that religious associations can claim from non-discrimination rules, but it does not necessarily eliminate the right altogether.

In order to analyze this complex issue, we considered two justifications for the immunity thesis (freedom of association and freedom of the church) as well as the impact of whether the discrimination is internal or external: the former is permissible, while the latter is rarely so. Following this, we demonstrated how widespread direct governmental support for religion is and briefly indicated why public funding should matter for the evaluation of the immunity thesis.

We then introduced a multivariable test to evaluate the immunity thesis in cases that involve discrimination conducted by publicly funded religious associations. The multivariable test considers: the centrality of the discriminatory practice; the internal/external 'type' of the discrimination; the measure of cost internalization; the quantity of funding; and the state of available access to status as a recognized, funded religious association. This multivariable test can help concerned parties navigate between two core goals desired in a policy regarding the extent of immunity granted to funded religious associations: to maintain associational religious autonomy and to defend individuals from discrimination. Such tests are never deterministic in the sense that what they measure (the details of the case at hand) and the weight each variable receives (also sensitive to the case at hand) necessarily require a measure of discretion by state agencies and courts; however, the test provides a novel, useful tool for tracking competing concerns while evaluating religious associations' claims to immunity from

73. The choice between cost internalization and multiple establishments will be informed by the empirical details of the relevant case. Considerations, such as how feasible it is for new institutions to be established and how many members there are in each religious group, must be taken into account. These considerations should assist legislators, decision-makers, and judges in identifying the correct remedy (i.e. cost internalization or multiple establishments) for these complex cases and cannot be pre-determined by the multivariable test. 
anti-discrimination rules. Indeed, the prevalence of direct public funding for religious associations in Europe, Canada and gradually even in the U.S. suggests the need for a consistent framework through which to address the legal, political, and normative intricacies of immunity when a religious association is governmentally-funded, and conducts discriminatory practices. 